\title{
PEMUDA DAN MEDIA DI ERA MILENIAL (SEBUAH REFLEKSI DI HARI SUMPAH PEMUDA) ${ }^{1}$
}

\author{
Oleh: M. Jamil ${ }^{2}$
}

Mengawali tulisan ini, patut kita ucapkan puji syukur atas kehadirat Allah SWT atas limpahan rahmat dan karunianya, sehingga pada momentum kali ini kita dapat berkumpul dalam satu momentum bersejarah, yakni dalam rangka peringati hari sumpah pemuda. Selain itu, patut juga kita sampaikan salawat serta salam kepada junjungan kita, sang refolusioner sejati, sang putra padang pasir, nabi agung Muhammad SAW., berkah jerih payahnya kemurnian-kemurnian berpikir masih dapat kita rasakan sampai detik ini. Penulis dan juga semua yang hadir pada saat ini juga kita harus ucapkan terimakasih dan syukur atas jerih payah semangat para funding father kita terdahulu, sehingga pada momentum kali ini, pada tiap tahunnya selalu kita rayakan atau peringati Hari Sumpah Pemuda.

Hari ini, pemuda seantero jagat nusantara termasuk pemuda Nusa Tenggara Barat (NTB) sedang riang gembira dalam suasana peringatan hari sumpah pemuda. Sebagai pemuda NTB, dalam momentum ini kita jadikan sebagai evaluasi diri, sejauh mana pencapaian dan kontribusi pemuda untuk bangsa dan negara ini. Sebagai pemuda NTB, kita harus berkontribusi nyata dalam memberikan sesuatu untuk tanah leluhur kita, sebagai tempat kita lahir dan dibesarkan, tanah sebagai tumpah darah kita. Pemuda NTB merupakan tumpuan masa depan kemajuan NTB kedepan. Keharmonisan dan kejayaan NTB kedepan,

\footnotetext{
${ }^{1}$ Tulisan ini pernah disampaikan pada Dialog Pemoeda NTB yang diselenggarakan oleh KEPMA Bima-Yogyakarta dalam rangka Hari Sumpah Pemuda pada 28 Oktober 2017, berlangsung di Asrama Mahasiswa NTB..

2 Ketua Umum Pusat Studi Mahasiswa Pascasarjana (PUSMAJA) Mbojo-Yogyakarta Periode 2015-2017 | | Ketua II Bagian Eksternal Dewan Pimpinan Cabang Perhimpunan Mahasiswa Hukum Indonesia Daerah Istimewa Yogyakarta (DPC PERMAHI DIY) Periode 20122014 | Email: jamilncera@gmail.com | FB/Youtube/IG/Twitter: @MJAMILSH | Website: http://www.mjamil.my.id.
} 
Terbit 28 Oktober 2017

"Pemuda dan Media di Era Milenial (Sebuah Refleksi di Hari Sumpah Pemuda)"

salahsatu unsur terpenting adalah termasuk sikap dan semangat kita sebagai pemuda.

Berkaitan dengan ini, sesuai keinginan kita bersama dalam momentum hari sumpah pemuda, Penulis coba membawakan materi tentang Pemuda dalam kaitannya dengan Media. Oleh karena itu, Penulis menyebutnya dengan tema "Pemuda dan Media di Era Milenial (Sebuah Refleksi di Hari Sumpah Pemuda)". Pada era milenial dewasa ini, sebagai pemuda harus melek literasi dan media, karena pada era ini banyak cara-cara yang elegan yang mampu mengubah cara pandang seseorang maupun kebijakan yang dikeluarkan pemerintah.

Point yang mencolok dari lahirnya sumpah pemuda adalah, adanya keinginan para pemuda dari masing-masing etnik bersedia untuk menomorduakan keinginan pribadi untuk menjadikan satu untuk Indonesia. Para funding father masa silam bersumpah untuk mengakui satu tanah tumpah darah, yaitu Indonesia, satu bangsa, yaitu bangsa Indonesia, dan menjunjung tinggi satu bahasa, bahasa Indonesia, mereka bersedia membatasi diri demi persatuan bangsa (Franz MagnisSuseno, 2008: 5). Kita sebagai pemuda yang hidup di era milenial, banyak hal yang bisa kita lakukan untuk menjiwai dan melanjutkan apa yang menjadi amanah yang tertuang dalam sumpah pemuda. Kita harus mampu menyampingkan keinginan pribadi kita untuk cita-cita luhur bangsa dan negara ini, agar bangsa kita menjadi bangsa besar dan disegani seantero dunia. Salahsatunya, pemuda harus berani tampil mengekspresikan keinginannya melalui media-media yang ada.

Pemuda terkadang malu mengirimkan gagasan-gagasan briliarnya ke media massa. Banyak faktor yang melatarbelakangi ketidakberaniannya, beberapa diantaranya merasa malu takut tidak disenangi pembaca, Pemuda harus menyadari perlunya bermitra dan bersahabat dengan media. Media erat kaitannya dengan dunia tulis-menulis (literasi). Oleh karena itu, sebagai pemuda harus melek media dan dunia kepenulisan, karena mengekspresikan diri dalam menulis itu sangat penting untuk menjadi sebuah catatan sejarah bagi penulisnya, lebih-lebih bagi kemajuan peradaban NTB kedepannya. 
Terbit 28 Oktober 2017

"Pemuda dan Media di Era Milenial (Sebuah Refleksi di Hari Sumpah Pemuda)"

Banyak potensi-potensi di NTB yang perlu disuarakan oleh pemuda sebagai para intelektual organik yang masih murni dari campur tangan dan kepentingan sesaat. Seperti potensi wisata alam, wisata budaya, wisata sejarah, serta hasil kreasi-kreasi lokal lainnya.

Terkait menulis, sebenarnya sudah dicontohkan oleh Allah SWT dalam AlQur'an Surat Yaasiin ayat 12, yang artinya, “Kamilah yang mencatat (menulis) setiap perbuatan yang telah dilakukan oleh manusia dan pengaruh baik atau buruk dari perbuatan itu sepeninggalannya. Semuanya itu Kami catat dengan teliti pada buku catatan amal yang mudah dibaca oleh pelakunya kelak di akhirat." Surat Yaasiin ayat 12 diatas jelas menggambarkan bahwa pencipta alam semesta saja menulis, walau apa yang Allah SWT tulis itu dilakukan melalui perantara malaikatnya yakni malaikat Rokib dan Atid. Sebagai manusia, lebihlebih kaum muda terpelajar mempunyai kewajiban moral yang sangat tinggi untuk mengembangkan serta berkontribusi untuk bangsa dan negara, salahsatu caranya adalah menulis. Konsep dan gagasan yang telah ditulis bisa dijadikan acuan solusi saat ini maupun untuk kemajuan masa akan datang.

Sangat besar manfaatnya kalau kita menuliskan gagasan-gagasan yang telah tertanam dalam benak kita, jangan biarkan membeku, jangan hanya kita mengungkapkannya dengan lidah kepada orang lain, karena dengan cuman mengungkapkannya itu tidak akan berdampak luas penyebaran gagasan-gagasan tersebut, oleh karena itu, sangat perlu kita menuliskannya sehingga dapat menjangkau lebih luas melampaui apa yang kita bayangkan. Seperti halnya Ibn alMuqaffa, seorang penulis Arab yang berasal dari Persia pernah mengungkapkan dalam tulisannya, "Ungkapan lidah itu terasa hanya pada sesuatu yang dekat dan hadir, sedangkan ungkapan tulisan itu berguna bagi yang menyaksikan dan yang tidak menyaksikan, bagi orang yang dulu dan yang akan datang. Ia seperti orang yang berdiri sepanjang waktu."

Mari kita berpikir sejenak, apa jadinya ayat suci Al-Qur'an kalau semasa nabi dan para rasulnya tidak dituliskan, mungkin saat ini kita tidak akan mengenal Al-Qur'an. "Orang boleh pandai setinggi langit, tapi selama ia tidak menulis, ia akan hilang di dalam masyarakat dan dari sejarah. Menulis adalah bekerja untuk 
keabadian." Begitulah celoteh Pramoedya Ananta Toer melalui salahstu karya fenomenalnya.

Banyak tokoh-tokoh besar membikin ia dikenang dan di agung-agungkan karena kisahnya dia tulis atau dituliskan. Oleh karenanya, ketika ingin dikenang, salahsatu cara yang ampuh adalah menulislah. Bung Hatta, Pramudya dan para tokoh bangsa lainnya semua dikenang karena mereka menulis. Begitu berharganya sebuah tulisan, sekelas Bung Hatta menjadikan buku sebagai maharnya ketika dia menikah. Hal ini dilakukan bukan karena alasan dia tidak memiliki uang, melainkan karena dia merasa buku adalah harga yang pantas dan tak terhingga bagi seorang pemikir. Buku bagi Bung Hatta adalah harta tertinggi dari setiap manusia. Tak tergantikan dan tak sebanding dengan tumpukan materi apapun. Setidaknya kita bisa buktikan betapa kecintaannya terhadap buku ketika dia meninggal, sekitar 10 ribu buku dia tinggalkan. Buku yang dia kumpulkan selama hidupnya. Dia benar-benar hidup sebagai pemikir dan intelektual sejati. Jumlah buku menjadi simbol kecintaanya pada alam pemikiran. Tulisannya terdokumentasi dengan baik akan menjadi penghubung masa lalu dan masa depan manusia. Itulah keyakinannya. ${ }^{3}$

Mari membudayakan diri dalam keseharian kita untuk menulis. Terus dan teruslah semangat untuk menulis, karena kita punya keterbatasan untuk menjalankan semua gagasan, konsep yang ada dalam pikiran kita, dan menulis adalah salahsatu cara yang ampuh untuk mewujudkan itu semua. Karena dengan tertuliskannnya ide dan gagasan itu, kita tidak akan berjalan sendiri, bukan tidak mungkin orang yang akan membaca ide dan gagasan itu yang akan menjalankannya. Pencapaiannya akan masif, bahkan mampu melampaui zaman.

Bersahabat dengan media dalam menumbuhkan jiwa menulis adalah suatu keharusan bagi pemuda sebagai intelektual organik, serta sebagai agen perubahan (agen of change) bahkan sebagai agen pengontrol (agen of control). Banyak media yang bisa dimanfaatkan untuk meneriakkan kebenaran dalam era milenial dewasa ini, seperti yang mudah diakses dan digunakan oleh semua orang yakni

3 Iskandar, 2016, "Kepemilikan Buku dan Bukti Kepantasan Para Pemikir", http://www.pusmajambojojogja.or.id, Diakses 24 November 2016. 
Terbit 28 Oktober 2017

"Pemuda dan Media di Era Milenial (Sebuah Refleksi di Hari Sumpah Pemuda)"

media sosial seperti facebook, twitter, instagram, dan media sosial lainnya. Dengan menggunakan media sosial yang ada, kita sebagai pemuda dapat berkreasi membuat meme-meme yang menarik perhatian khalayak ramai dan tentunya halhal yang positif bukan semata menyebarkan kebohongan (hoax) yang meresahkan masyarakat. Alternatif lain juga bisa kita manfaatkan bloger-blogger yang tidak berbayar, dan bisa dengan mudah kita manfaatkan untuk menyebarkan firus-firus kebaikan.

\section{REFERENCES}

Franz Magnis-Suseno, 2008, Etika Kebangsaan Etika Kemanusiaan: 79 Tahun sesudah Sumpah Pemuda, Penerbit Kanisius, Yogyakarta.

Sambutan M. Jamil dalam Tim Penulis PUSMAJA, 2017, Bima Berubah: JejakJejak Gagasan Intelektual Muda, Pusat Studi Mahasiswa Pascasarjana (PUSMAJA) Mbojo-Yogyakarta, Yogyakarta.

Iskandar, 2016, “Kepemilikan Buku dan Bukti Kepantasan Para Pemikir", http://www.pusmajambojojogja.or.id, Diakses 24 November 2016

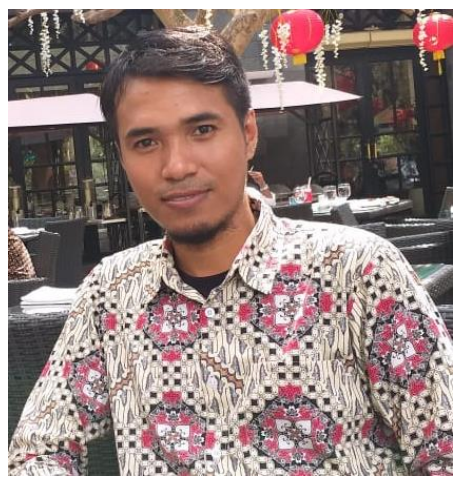

Penulis: M. Jamil, S.H.

Ketua Umum Pusat Studi Mahasiswa Pascasarjana (PUSMAJA) Mbojo-Yogyakarta Periode 2015-2017 | Ketua II Bagian Eksternal Dewan Pimpinan Cabang Perhimpunan Mahasiswa Hukum Indonesia Daerah Istimewa Yogyakarta (DPC PERMAHI DIY) Periode $2012-2014$

\section{Ful Sumber Tulisan:}

M. Jamil, "Pemuda dan Media di Era Milenial (Sebuah Refleksi di Hari Sumpah Pemuda)", dimuat di https://www.pewarta-news.com/2017/10/pemuda-danmedia-di-era-milenial-sebuah.html, pada 28 Oktober 2017. 